\title{
THE LOW - BUDGETING CONCEPT OF BACKPACKING
}

\author{
JOLANTA BARBARA JABŁONKOWSKA, ${ }^{1}$ BOGUSŁAW STANKIEWICZ ${ }^{2}$ \\ ${ }^{1}$ University School of Physical Education in Wroclaw, POLAND \\ e-mail: jolanta.jablonkowska@awf.wroc.pl \\ ${ }^{2}$ The Jacob of Paradise University in Gorzow Wielkopolski, POLAND \\ e-mail: boguslaw.stankiewicz@zut.edu.pl
}

\begin{abstract}
RECEIVED
25 November 2017

ACCEPTED

15 December 2017

JEL

CLASSIFICATION

Z32

KEYWORDS backpacking, economy, low budget, motivation, travel

ABSTRACT Low-budgeting is one of the most important pillars of backpacking. It is considered to be the primary determinant of this type of travel. Because the cheapness, economic efficiency of spending money, the calculation of expenditure, determines the practical dimension of this type of tourism. It allows to take trips to the most distant regions of the world, to all those (especially young people) who do not have sufficient financial backing, to benefit from the offers of tour operators. Hereby a part of the scientific community understand the low-budgeting and see a specific financial backpacker's tactics in it. Others, in turn, notice more and more widespread loosening of budgetary discipline among backpackers, their free approach to economic issues and not limiting travel expenses. To describe the concept of low-budgeting in backpacking, to understand its essence and determinants, the survey was conducted in 2015/2016. The study involved 100 respondents between 22 and 35 years old who identify with backpacking and did at least one such a trip. The socio-economic issues of backpackers ' travel, material backpackers' compensation and the economic motives of the trips they undertook were analysed.
\end{abstract}

\section{Introduction}

It is acknowledged that the low financial outlay for a trip is a pillar of backpacking, as are three others: independent of the tourism industry and self-sufficient way of planning and executing the journey, as well as deciding the direction of the expeditions (Pearce, 1990, 2006; Cohen, 2004; Pearce, Murphy, Brymer, 2009). In Australia this type of travel is included in the international budget tourism sector [sub-sector of international budget tourism] 
(Hampton, 1996, 1998) justifying that it is characterized by the choice of travel practices that favour and enable the preservation of low-budget discipline. "Backpackers - as recorded in the development strategy of one of Australia's administrative regions - are less susceptible to fluctuations in the economy and more flexible in the face of the economic challenges of the world" (Backpacker tourism action plan 2009, p. 2). The backpackers themselves admit that "they can sleepover in most countries of the world for less than 10 polish zloty or even for free (...). They eat what the natives (...). They usually use local communication, hitchhiking or on their own feet. Most backpackers follow the rule that they will eat and sleep well at home" (Sachno, 2008, p. 56). The cheapness is the particular advantage of this style of tourism (Jabłonkowska, 2016; 2017). However, as Dłużewska remarks (2004, p. 27; 2007), backpacking should not to be confused with the Tatra mountain hiking, nor with the lack of money. Traveling with a backpack is not vagabonding "in most cases" - explain Patyra and Dłużewska (2015, p. 44) - "is not due to poverty, but to the chosen philosophy of travelling".

In recent years, the backpackers' society has been promoting the loosening of low-budget discipline. Many backpackers do not limit travel expenses, especially if they are directly linked to their need of experiencing and learning. They think that when they come to a place, they should take full advantage of the opportunities offered to them. So they are ready to pay almost any price for services that will enable them to fulfil their desires (Grygiel, 2010).

So how to interpret low-budgeting in backpacking? What practices fit into the financial backpackers' tactics? In order to answer these questions, there was conducted the study of socio-economic conditions of backpackers' travel, their material salaries and the economic motives of their trips were analysed. The survey, conducted from November 2015 to February 20161', involved persons who identified themselves as backpackers and had at least one expedition in this type of travel. There were 100 persons ( $41 \%$ male, $59 \%$ female). The median age of the respondents was 25 years (the youngest was 22 years, the oldest was 35 years), $41 \%$ of the respondents were unemployed, $35 \%$ declared informal relations, $17 \%$ married, and $7 \%$ were divorced or widowed (widowers). The respondents were mainly from cities $(76 \%)$, had higher education (42\%) or medium $(34 \%)$, after vocational school there were only $23 \%$ of people, and elementary $-1 \%$. $65 \%$ of surveyed backpackers carried out more than 4 backpackers' journeys; almost every fifth respondent had 2-4 expeditions, and for $14 \%$ backpackers such a trip was a one-time experience. The survey was used asking about the socio-economic conditions of the backpackers' trips (related to the preparation and execution of the trip, sources of its funding, the work undertaken during the expedition).

\section{The financial conditions of hackpackers}

The material background of the surveyed backpackers (Figure 1) does not allow for an unequivocal conclusion about their poor financial condition. Over half of them (66\%) rated their financial situation as good $(51 \%)$ and even very good (15\%). Only $28 \%$ - as average and only $6 \%$ - as insufficient.

1 The research was carried out by Marta Cieplicka, a student of West Pomeranian University in Szczecin, unpublished master's thesis: Backpacking as a form of practicing contemporary tourism among people aged 20-35 together with socio-economic aspects, thesis supervisor prof. B. Stankiewicz. Assistant thesis supervisor dr Jolanta B. Jabłonkowska. 


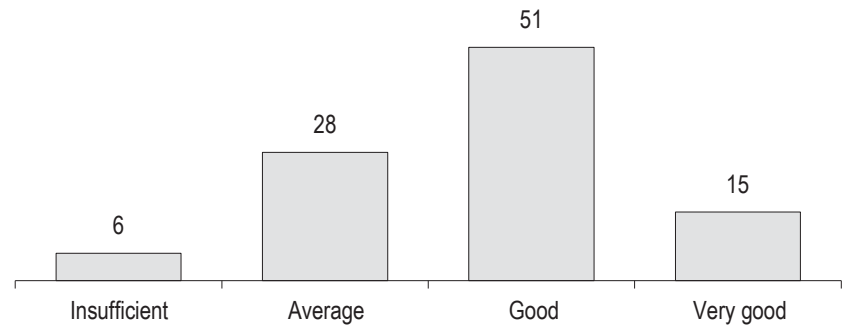

Figure 1. The financial evaluation of respondents (\%)

Source: own compilation based on M. Cieplicka, Backpacking as a form of practicing contemporary tourism among people aged 20-35 together with socio-economic aspects (unpublished master's thesis).

Backpacking - as the data indicate - do not choose people with small financial resources. Such situations are rare and concern only $6 \%$ of the examined backpackers (their material conditions - in their opinion - are inadequate). For the most part, however, the choice of low-budget travel is the result of their voluntary choice. It's a skill. "Cheap Travel (...) - it is style, fashion, not necessity. Backpackers are generally well-off people, can afford airplanes and appropriate clothing - warm Gore-Tex jackets, special cotton underwear that does not soak. And also gadgets like self-contained mattresses or water bottles, adjusting to the shape of the free space in the backpack" (Więcka, 2002, p. 78).

The "cheap" travel organization skill goes beyond the simplistic concept of low-budget tourism. You have to have a certain amount of financial resources to be able to afford to meet your travel needs. The expenses associated with backpacking travel are in many cases far higher than those incurred by so-called mass tourists (Loker-Murphy, Pearce, 1995; Newlands, 2004; Hannam, Diekmann, 2010). Backpackers are consumers (like the mass tourists) of tourist and recreational attractions that require some financial independence and wealth (Shields, 1992; Cooper, O'Mahony, Erfurt, 2004). But with the difference in terms of institutionalized tourists, they do not consume ready packages, but they make their own decisions about financing their next stages of travel according to their individual expectations, associated with experiencing pleasure, time and economic capabilities.

Many researchers believe that, backpackers travel on a low budget, with strict spending limits. They choose cheap accommodation, cheap means of transport, inexpensive ways of eating, etc. Therefore, they are suggested to be called "budget travelers" (O'Reilly, 2006, p. 1005-1006). In order to check the amount spent on travel, the respondents were asked about the average expenses they incurred during the week. The respondents marked their declarations using scales of answers containing quota ranges.

The analysis of the expenses that the respondents incurred during the trip indicates that when they arrive at the destination they do not limit their expenditures. 37\% of them spent $250-500 \mathrm{z}$ in the destination within a week; $31 \%$ - over $501 \mathrm{zł} \mathrm{(some} \mathrm{even} \mathrm{above} \mathrm{1,000} \mathrm{zł),} \mathrm{whereas} \mathrm{the} \mathrm{minimum} \mathrm{spending,} \mathrm{not} \mathrm{exceeding} 250 \mathrm{zł}$, was declared by $32 \%$ of respondents (Figure 2 ). 


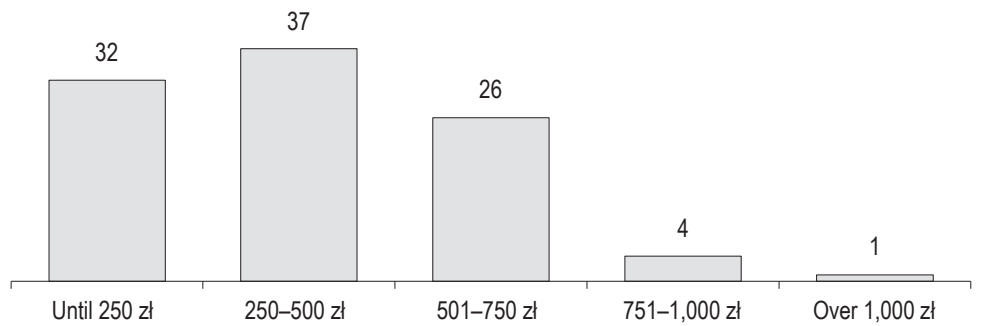

Figure 2. The range of weekly expenses during travel (\%)

Source: own compilation based on M. Cieplicka, Backpacking as a form of practicing contemporary tourism among people aged 20-35 together with socio-economic aspects (unpublished master's thesis).

The most amount of money backpackers spend on food. Figure 3 shows the structure of expenditure incurred by respondents during their departure. The living needs significantly outweighed the costs: food purchases (100\% of indications). Not every respondent used the available accommodation facilities, so the fees related to accommodation indicated $67 \%$ of the respondents. The separate expenditure group included needs of cognitive nature: related to cognition and experiencing (purchase of admission tickets for tourist and recreation attractions $47 \%$ ). The lowest was the amount spent on the use of alcohol and cigarettes, declared by only $7 \%$ of respondents.

The above declarations indicate that expenditure related to the implementation of backpackers' travel is not low, which seems to deny universal opinion about the "cheapness" of backpackers travel. The effect of this apparent discrepancy is probably the specifics of this type of trip and the nature of the backpackers themselves. Therefore, caution should be kept when formulating final conclusions about the economic backpacking conditions and consider the issue of expenditure flexible.

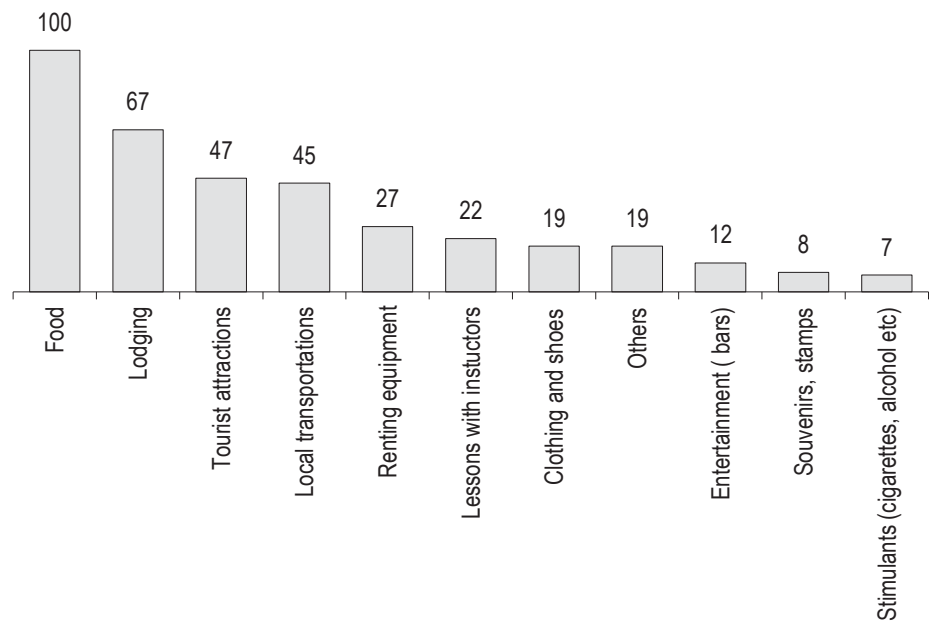

Figure 3. Backpackers expenses (\%)

Source: own compilation based on M. Cieplicka, Backpacking as a form of practicing contemporary tourism among people aged 20-35 together with socio-economic aspects (unpublished master's thesis). 
Issues related to the financing of backpacking trips are also important. The respondents were asked about ways to raise money for their backpacking trip (Figure 4).

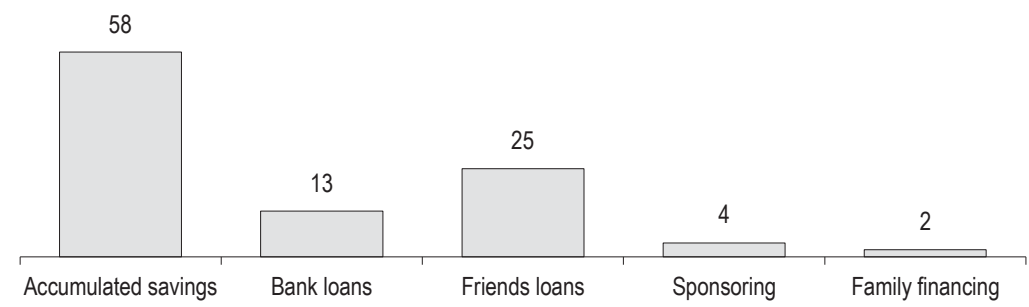

Figure 4. The financing sources of trips (\%)

Source: own compilation based on M. Cieplicka, Backpacking as a form of practicing contemporary tourism among people aged 20-35 together with socio-economic aspects (unpublished master's thesis).

Respondents pointed out that their trips are mainly funded by pre-existing savings (58\%). Every 4 people borrow from family or friends. Some benefit from the help of institutions (13\%), even less from sponsorship.

Respondents were also asked about the forms of taking up employment while traveling. $28 \%$ of respondents said that part of their time spent on work to finance their own trip. Among the answers about the specifics of the work done there were examples of: mobile jobs in the IT industry (13\%); playing musical instruments (5\%); letting soap bubbles in the streets (6\%); temporary and short-term work on the farm (4\%).

The knowledge of the economic backpackers' salaries was supplemented by information on the market value of the equipment they carry with them (Table 1). The warrantor of securing the many needs of backpackers is good quality equipment. The price of equipment that they take with them depends to a large extent on the materials they are made from, the quality, the weather and damage resistance. The question about the money sources the respondents spend on the equipment would not reflect their financial capacity to prepare a low budget trip, but to indicate what resources they use on the various elements of their backpacking allowance and also - what is their special value in choosing the equipment. Basic equipment is the cost of approximate $1640 \mathrm{z}$. Converted into average expenditure on travel, assuming that equipment is exploited on average in 5 years - basic equipment represents $13.32 \%$ of the average amount spent on a given trip.

Table 1. The money the respondents are willing to spend on a given item of equipment

\begin{tabular}{lccccc}
\hline & \multicolumn{5}{c}{ Financial value of equipment $(\mathrm{z})$} \\
\cline { 2 - 5 } \multicolumn{1}{c}{ Equipment } & $0-200$ & $200-500$ & $500-1,000$ & $1,000-1,500$ & Over 1,500 \\
\hline Shoes & 28 & 43 & 26 & 3 & 0 \\
Backpack & 30 & 41 & 19 & 10 & 0 \\
Tent & 19 & 35 & 29 & 15 & 2 \\
Sleeping bag & 43 & 27 & 14 & 39 & 0 \\
Digital camera & 0 & 0 & 24 & 55 & 47 \\
Video camera & 0 & 5 & 19 & 2 & 16 \\
Electronic book reader & 38 & 41 & & 6 \\
\hline
\end{tabular}

Source: own compilation based on M. Cieplicka, Backpacking as a form of practicing contemporary tourism among people aged 20-35 together with socio-economic aspects (unpublished master's thesis). 
The respondents spend most on electronic equipment, obtaining good cameras and cameras, spending the least on a sleeping bag.

The most significant factor in selecting the items is the price, although the respondents also pay attention to other criteria. The quality, weight and opinion of other users are also important. The origin of the product took fifth place on the scale. However, the brand and fashion are of little importance.

\section{Economic motives of taking up backpacking}

Respondents were asked about their motivations to choose backpacking (as a consciously approved form of travel) and the preferences of the places they visited. The answers to the question concerning the first part were related in many cases to low-budgeting. $19 \%$ of respondents opt for backpacking because of low travel costs, $27 \%$ due to their limited budget. But the motives associated with economics were not the most numerous. The social aspects of tourism were more important. For $36 \%$ of respondents, the preparation of such a trip involved the pleasure of self-organization and personal design of the way to spend free time; for $39 \%$ - with satisfaction resulting from coping with difficult conditions; for $29 \%$ - with the need of meeting new people from different parts of the world and from different cultures; for $25 \%$ - spending an unlimited amount of time at a particular place according to personal design. In the other categories were as follows: "no one except me has my time", "I decide for myself" (25 points); "I develop my personality", "I develop different skills and broaden my horizons, which will be useful in my personal and professional life" (17 references); "A good way to learn foreign languages" (31 references). The respondents also pointed out (these were individual answers - 4\%) on: the educational aspect of backpackers' travel, the temporary possibility of getting rid of daily duties, lack of interest in other forms of tourism.

The analysis of the countries, the examined backpackers visited during their backpacking trips, also does not allow concluding on the economic basis of these choices. Among the most popular European countries were Croatia and Montenegro (64\%); Albania, Bosnia and Herzegovina (51\%), Romania, Bulgaria, Moldova (49\%), France, Monaco (43\%), Greece, Macedonia (41\%), Belgium, the Netherlands, Denmark, Luxembourg (32\%), Kosovo, Serbia (31\%), Italy (27\%), Austria, Germany, Liechtenstein (19\%), Turkey (15\%), Malta (10\%), Belarus, Ukraine (10\%), Russia (7\%). Among the Asian countries, there were indications of Georgia (24\%), India (13\%), China (9\%), Vietnam (9\%), Cambodia (7\%), Laos (3\%), Nepal (2\%), Thailand (1\%), Japan (1\%). From the North America: the United States (7\%), Canada (4\%), Mexico (4\%), Panama (2\%), Cuba (1\%), Costa Rica (1\%). In South America, it was Bolivia (3\%), Venezuela (2\%), Brazil (1\%). In Africa, respondents travelled to Morocco (8\%), Egypt (3\%), Zimbabwe (1\%), Cameroon (1\%). In Australia and New Zealand, one respondent indicated his travel presence at this place.

The catalogue of indicated countries does not reflect any economic regularity. You cannot find in these choices the differences between the rich and the poor. The respondents visited both the countries of the economic prosperity as well as the ones which are in the process of achieving this goal. It can also be noted, however, that European countries dominate as well as former socialist countries.

\section{Conclusions}

Backpacking appears as an intrinsic activity in the philosophy of life, which has its roots in both the stage of human life and its materialistic side. Although low cost travel arrangements for most backpackers seem to be part of their conscious choice and style of spending their leisure time, rather than the necessity of their overall bad financial situation. 
Backpacking is a type of tourism which fits more in with social relationships than in economic algorithms. Low budgeting should be understood as an orientation on "cheapness" stemming from the desire to impose budgetary rigor to spend according to "personal" needs, most often in the reverse to mass tourism: the least money spent on the basic needs of life functions and much more for higher needs - self-fulfillment needs : promoting personal development, strengthening self-esteem, improving physical and mental health, developing economic, political and historical knowledge and practical skills useful in private and professional life. If there are no funds to continue the trip then backpackers undertake part - time jobs.

\section{References}

Backpacker tourism action plan 2009-2013 (2009). Melbourne: The Victorian Government.

Cohen, E. (2004). Backpacking: Diversity and change. In: G. Richards, J. Wilson (eds.), The global nomad: backpacker travel in theory and practice (pp. 44-46). Clevedon: Channel View Publications.

Cooper, M., O'Mahony, K., Erfurt, P. (2004). Backpackers: Nomads join the mainstream? An analysis of backpacker employment on the 'harvest trail circuit' in Australia. In: G. Richards, J. Wilson (eds.), The global nomad: Backpacker travel in theory and practice (pp. 180-195). Clevedon: Channel View Publications.

Dłużewska, A. (2004). Bag Packers czyli ludzie z plecakiem. Biznes i Turystyka, 25, 26-32.

Dłużewska, A. (2007). Backpckers: New Nomads or Escapists? In: C. Geoffrey, R. Sibley (eds.), Going abroad: travel, tourism, migration. Cross - Cultural Perspectives on Mobility (pp. 167-176). Newcastle: Cambridge Scholars Publishing.

Grygiel, M. (2010). Sustainable Backpacking: Understanding the Ecological and Cultural Footprint of Backpackers in the Byron Bay Community. Villanova: Villanova University.

Hampton, M.P. (1996). Economic Development Impacts of Backpacker Tourism in the Periphery: A Case Study of Lombok. Portsmouth: University of Portsmouth, Department of Economics.

Hampton, M.P. (1998). Backpacker tourism and economic development. Annals of Tourism Research, 3 (25), 639-660.

Hannam, K., Diekmann, A. (eds.) (2010). Beyond Backpacker Tourism: Mobilities and Experiences. Bristol UK: Channel View Publications.

Jabłonkowska, J.B. (2016). Tożsamość współczesnego backpackera - między kontrkulturowością a indywidualizmem. Ekonomiczne Problemy Turystyki, 1 (33), 273-286.

Jabłonkowska, J.B. (2017). Backpackerzy polscy a zagraniczni. Wieloaspektowe studium porównawcze. Wrocław: AWF we Wrocławiu. Loker-Murphy, L., Pearce, P. (1995). Young Budget Travelers: Backpackers in Australia. Annals of Tourism Research, 4 (22), 819-843.

Newlands, K. (2004). Setting out on the road less travelled: A study of backpacker travel in New Zealand. In: G. Richards, J. Wilson (eds.), Global Nomad. Backpacker Travel in Theory and Practice (pp. 217-236). Clevedon: Channel View.

O'Reilly, C.C. (2006). From Drifter to Gap Year Tourist: Mainstreaming Backpacker Travel. Annals of Tourism Research, 4 (33), 998-1017.

Patyra, A., Dłużewska, A. (2015). Backpacking - historia, ramy, rozwój. Turystyka Kulturowa, 11, 40-54.

Pearce, P.L. (1990). The Backpacker Phenomenon: Prelimunary Answers to Basic Questions. Townsville: James Cook University of North Queensland.

Pearce, P.L. (2006). Backpackers and backpacking - a fresh look. Tourism Recreation Research, 3 (31), 53-59.

Pearce, P.L., Murphy, L., Brymer, E. (2009). Evolution of the backpacker market and the potential for Australian tourism. Sustainable Tourism Pty Ltd, Gold Coast, Queensland.

Sachno, S. (2008). Następcy Marco Polo. Jak za tysiąc euro dotrzeć na koniec świata. Wprost, 31, 56-59.

Shields, R. (ed.) (1992). Spaces for the subject of consumption. In: R. Shields (ed.), Lifestyle shopping: The subject of consumption (pp. 1-20). London: Routledge.

Więcka, A. (2002). Na własnych nogach na koniec świata. Newsweek Polska, 3, 76-80.

Cite this article aS: Jabłonkowska, J.B., Stankiewicz, B. (2018). The low - budgeting concept of backpacking. European Journal of Service Management, 2 (26), 123-129. DOI: 10.18276/ejsm.2018.26-15. 